\title{
FUNDAMENTAL PREREQUISITES TO CREATE A PSYCHOLOGICAL PARADIGM SHIFT IN STUDENTS' DEGREE CHOICE
}

\author{
Lalith Edirisinghe ${ }^{1 凹}\left(\mathbb{D}\right.$, Sampath Siriwardena ${ }^{2}$, Lakshmi Ranwala ${ }^{3}$ \\ 1,2,3 Faculty of Management and Social Sciences, CINEC Campus, Sri Lanka Lalith Edirisinghe, Faculty of \\ Management and Social Sciences, CINEC Campus, Sri Lanka.
}

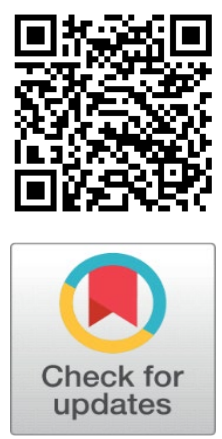

Received 15 September 2021

Accepted 15 October 2021

Published 31 October 2021

CorrespondingAuthor

Lalith Edirisinghe,

lalith.edirisinghe@cinec.edu

DOI

10.29121/granthaalayah.v9.i10.2021 .4339

Funding: This research received no specific grant from any funding agency in the public, commercial, or not-for-profit sectors.

Copyright: (C) 2021 The Author(s). This is an open access article distributed under the terms of the Creative Commons Attribution License, which permits unrestricted use, distribution, and reproduction in any medium, provided the original author and source are credited.

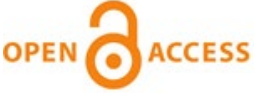

\section{ABSTRACT}

With globalization the need for experts in various fields were identified. In Sri Lanka students and parents preferred to become engineers, medical doctors, accountants, and lawyers after completion of their studies. However, demand for jobs other than above categories kept increasing and a mismatch between the supply of qualified people in relevant fields as against the demand from industry and government generated. Government universities offered degrees in limited fields and students were compelled to enroll in degrees against their choice. The education system produced more graduates from certain fields that are not in demand from the industry perspective. This situation leads to unemployment and underemployment which is a social problem today. Therefore, a psychological paradigm shift in students' degree choice is proposed in this paper as a long-term solution to this problem. This study administered a qualitative research approach consisting comprehensive desk research and opinion survey. The results reveal the seriousness of the problems in Sri Lanka, its root causes, potential solutions. The society in large has settled down with certain ideologies about the field of higher education that are not commensurate with the present global trends. This paper discusses about the fundamental prerequisites to create a psychological paradigm shift in students' degree choice.

Keywords: Education, Psychological Paradigm, University, Choice, Students

\section{INTRODUCTION}

Education sometimes referred as a "non-utility" function. Generally, the students enter to tertiary education with the objective of gaining the primary qualification to secure a job of his choice. Therefore, the degree choice, in most cases, is derived from the type of employment he or she prefers to engage after graduation. Although the study sessions do not provide "utils" the indispensable need of passing examinations and successful completion of the degree creates motivation for education. Except for those who achieve the highest scores in examinations and other assessments at pre-tertiary level, may not experience education as a utility function. As a result, once they secure a job, their formal education ends as most of them consider the employment as the destiny of formal education. However, those who employed in certain fields such as academia need continuous improvements of their qualifications to climb up in the career ladder may further their studies provided the financial strength. Such students may find "utils" in education particularly beyond the basic degree. While this is the common scenario, there are exception to nun-utility nature in education. For example, a student who obtained very good results up to secondary education 
may find utils and consider education as a part of their life. Students' choice for a degree, is therefore, a complex phenomenon that needs comprehensive analysis. The psychological paradigm of a country may be distinctive or unique to their citizens. Like in all other industries this paradigm may be influenced by political, economic, social, technological, environmental, ecological, and legal (PESTEEL) factors.

There are two different Latin roots of the English word "education." They are "educare", which means to train or to mould, and "educere", meaning to lead out Craft (1984). Undergraduate education is a significant milestone in school leavers as the future career also affected by this selection. On the other hand, ensuring that its graduands are employable is a central issue for a university. This can be achieved only by identifying the critical elements in advance and determining the causes for them Ramanayake and Pathiratne (2012). The country will develop only if the right candidates are constantly delivered to the industry and other administrative institutions through the university system. Therefore, it is important that degree programs are very well aligned with the countries current and future demands. However, it is evident that many countries suffer from underemployment of unemployment. History reveals the imbalance between demand from public and private employments and supply from qualified candidates have given rise to various economic and social problems. The critical reality of the problem is that this imbalance become noticeable after some time and it is hardly possible the reverse the situation then. For example, students enter to a specific academic discipline today will transform to a graduate in three or four years. The ideal option for today's industry demand may not necessarily the reality after four years. By the time the consequences start influencing the economy many candidates already in the pipeline become a heavy burden to the country. Therefore, students should have a fair knowledge of global trends (opportunities and threats) and his or her capacity to follow a specific academic field (strengths and weaknesses) ensuing the right choice.

Although this scenario has been in existence since the beginning of university system it is not possible to control this by bringing rules and regulation. Students internationally have their civil or social, constitutional, contractual and consumer rights. They invest their time and money. A wrong selection (among many options available) lead to a lot of disappointments and usually irrevocable. The time spent can be never bought back. Education as a fundamental human right lies at the heart of United Nations Educational, Scientific and Cultural Organization (UNESCO)'s mission and is enshrined in the Universal Declaration of Human Rights (1948) and many other international human rights instruments UNESCO (2021). The right to education is legally guaranteed for all without any discrimination. states have the obligation to protect, respect, and fulfil the right to education. The combination of government's vision, student rights, and freedoms usually regulate and facilitate for the educational investment. If the state is unable to provide enough choices that suits the global demands for the forward three decades at least the students in that country is deprived the best contribution of most educated generation. On the other hand, if the students (influenced by their parents/siblings) are not competent to select the best choice from what is available it is even greater loss to the country. Since the globalization has made the world a village through technology students can obtain the right choice of tertiary education by migrating to a developed country provided the finance is not a problem. But lack of knowledge selecting the most appropriate academic discipline could be a very unfortunate situation for both the student as well as the country. Each graduate not rightly aligned to the country's global demand become a huge burden to the economy and social frustration. 
The industrial inclusiveness in university curriculum (IUC) plays a strategic role in shaping the education system in a country enabling to achieve its sustainable development agenda Edirisinghe et al. (2021). If a country realises that the demanded job categories in government and private sector cannot be catered to by the existing inflow of undergraduates produced by the universities, the careful review in the supply side is indispensable. A new paradigm is needed for planning and financing higher education in Sri Lanka IBRD (2009). If the university system is not capable producing the demanded categories policy decisions to be brought in. however, clear evidence is available in some countries that students' degree choice is very myopic. For example, Sri Lanka lacks a framework or mechanism for university selection based on students' qualifications, skills, or choice Ranwala et al. (2020). In other words, they tend to select from very narrow fields of expertise due to traditional experiences and practices. This creates various medium- and longterm repercussions on the country's economic condition Edirisinghe et al. (2018)(Edirisinghe L., Factors Affecting the Choice of Higher Education in Logistics and Transport in Sri Lanka, 2018). Such circumstances pave the way to create a psychological paradigm shift (PPS) in students' degree choice. This paper focuses on the fundamental prerequisites in a country to create a PPS.

\section{Career Choice}

UNESCO is the only UN agency with a mandate in higher education UNESCO (2021a). In line with Target 4.3 of Sustainable Development Goal 4 to "by 2030, ensure equal access for all women and men to affordable and quality technical, vocational and tertiary education, including university," Psychometric tests, therefore, may be useful for students to discover their unknown skills and talents inside them, as well as appreciate and self-evaluate their inherent values thereby decide which academic career path to take on the way to the employment destiny. Career choice has become a complex science with the advent of information technology, the emergence of post-industrial revolution and job competition Koech et al. (2016). It is common in these days those candidates face a psychometric test prior to decide the pathway to the employment. Psychometric tests are the scientific ways primarily to explore a person's attitude, skills, and interests to assess their personality. Secondly, in the ability section, it measures a candidate's aptitude and skills, logical reasoning, and deduction. Therefore, psychometric tests are assessment tools. It helps to match a person's abilities and personality to a suitable career or role. Other important aspect is that it signals which specific personality group you fall into in terms of skill sets, ambitions, and aspirations. This is crucial because it's then easier to assess what type of employment/career might be suited to the respective candidate. Mostly it is used as a part of the recruitment process for hiring employees to multinational companies. Career planning is very important especially for the students from 10th to higher classes. The importance of psychometric test are as follows Lifology (2021).

In old days the selection of academic discipline was not complicated. The choice of employment also was not much different either. Traditionally, a famers' sons followed their father's footsteps, and ended up in farming. Other key jobs such as medical partitioners, teachers, lawyers, engineers in most cases found it convenient to learn the knowhow through the family background and ended up of being employed in similar jobs. 


\section{Psychological Paradigm}

In scientific perspectives and as a philosophy, a paradigm is a unique set of concepts or ideologies that sets standards for what constitutes a commonly accepted contributions to a field or society. It focuses on a context or a situation can be looked at and provides the basis for the way of thinking and acting accordingly. So, the direction may not change but could experience expansions over the years. American Psychological Association defines it as a set of assumptions, attitudes, concepts, values, procedures, and techniques that constitutes a generally accepted theoretical framework within, or a general perspective of, a discipline APA (2021). Since there are not much literature about the "psychological paradigm" researchers noted the importance of defining this combination in social context. Social psychology traditionally has been defined as the study of the

ways in which people affect, and are affected by, others Fussell and Krauss (2021). The common understanding is that psychology is the science of mind and behavior which is an academic discipline that covers both natural and social sciences.

A paradigm shift occurs when one paradigm is replaced by another. As a theory a paradigm helps to provide scientists a broader theoretical framework. The theoretical opinions, therefore, may change during a paradigm shift. A Psychological paradigm shift results in multicultural perspective Pedersen (2001). Understanding rather than measuring, predicting consequences rather than causation, social significance rather than statistical significance, subjectively derived rather than objectively are the qualities which were derived in a psychological paradigm shift. The term psychological paradigm shift is derived through term physical science, but it has a difference when it comes to the applicability to the depth psychology. Usually, parents are involved in guiding and providing financial support, but student are the ones that make the final call regarding the choice of Institution Junejo et al. (2019). Career choice is a complex decision for undergraduate students since it determines the kind of profession that a student intends to pursue in life Koech et al. (2016).

Are women moving into fields traditionally dominated by men, such as science and computing? These are just some of the questions faced by policymakers looking to expand and diversify their national tertiary education systems uis unesco (2021). Several studies developed frameworks to model undergraduates' university choice, for example three-stage model by Hossler (1987), Conceptual model by Perna (2006), FLAG (Fits Like a Glove) model by Allen (2002) etc. Cho (2008) et al looked at the roles of gender, race and Socioeconomic status in college choice and identified psychological, personal and institutional factors jointly impact the university selection process but this relationship is moderated by ethnicity, gender and family income. These findings are based on 1539 respondents of students attending four different universities, public, private, urban and rural areas. When paying attention on the demographic factors, family income Cho et al (2008) and Parental education Cho et al (2008), Giuseppe (2015) plays influential roles in university choice. Education should provide people the knowledge that they need to elect capable leaders. However, the conflicts in many countries show that public is lack of the needed intelligence for that critical task.

They have failed to see through the manipulations used by politicians to get votes citing prosperity and solutions for other pain points of the people. Accordingly, the members of the society suffer in many countries despite the education is supposed to have provided awareness so that they can vote for the 
leader who is best able to run the society. With the rapid development of international transportation systems people were exposed to any place in the world. They show the resources in other countries which were scarce in their own country. They had two options, firstly they tried to acquire the lands by force and fought with original citizens there and got themselves established. This created war between countries. Secondly, they attempted to use the resources in other countries cooperatively, through exchange of resources. This was known as barter system. It is an old method of exchange of resources without an intermediatory tool such as money. This system has been practised for centuries and long before money was introduced. People negotiated to exchange goods (and even services) for other goods and services in return. This evolution not only minimized the war to acquire resources but also influenced people to build relationships and harmony to sustain the business. The value of bartering items is negotiable with the other party. People needed certain disciplines to keep these long-term relationships intact. From the bater system it transformed to a more advanced and complicated system of trading using g money as an interim tool. Education helped promote tolerance in a society and helps reduce common conflicts between diverse population. In bigger countries this evolution took place even within domestic levels. They have people speaking different languages with many religions, casts etc. Therefore, conflict is always possible. The highest result of education is tolerance. As many philosophers reiterated Educating members of society about other people have the power to reduce many conflicts as it helps people to be patient. Education has the power to sustain in harmony and help societies to realise the difference between animals and human beings. The world has changed over the years for the better. According to Nelson Mandela, "Education is the most powerful weapon which you can use to change the world.

Under these circumstances it is important countries carefully study the trends of their students' degree choice to ensure they are aligned with global demands. Therefore, while understanding the determinants of students' choice in the undergraduate studies is vital it also necessary to analyse how such paradigms could be shifted in a predetermined direction. For example, if there are many underemployment and unemployment cases in a country it simply reflects the mismanagement of tertiary education pathway by respective authorities. The next step is to identify the root cause for these gaps. It could be either lack of degree programs in the demanding academic disciplines or the lack of competence of selecting the best option. These analyses need a scientific approach because the trends could change from the time students start their degree to the time, they complete the program which is four years in general. In such circumstance the psychological paradigm of program choice by students should be shifted in the right direction welcoming the everchanging global demands. However, manipulating with psychological paradigms is easier said than done. This study focuses on the fundamental prerequisites to create a shift in psychological paradigm of students' degree choice

\section{METHODOLOGY}

The research was conducted in Sri Lanka and the target population of this study consisted selected top official in Ministry of education, vice chancellors, deans of various faculties in private and government universities, School principals, teachers, and students, staff members of Technical colleges, officers of carrier development unit of higher education institutes, representatives from a university alumnus, current students in state and private universities, lecturers in state and private universities covering the supply side, Since the objective of the paper is to 
identify the potential prerequisites to create a shift in the psychological paradigm of students' degree choice, the researchers conducted an opinion survey to collect primary data and a desk research to substantiate the claims. A shift in university selection has become indispensable because there is an existence of a gap between the supply of graduates by educational institute and the demand for qualified candidates in the industrial establishments and service organizations. This disparity has led to a social problem in the country. For example, every successive government in Sri Lanka extended political solutions such as absorbing the graduates to the state sector employment as a temporary solution, but the root cause has not been resolved. However, it only makeshift the core issue from "unemployment" to "underemployment". Therefore, the fundamental problem remains unresolved and the graduates and industry sector both cotinine to suffer. In other words, supply side (graduates) and demand side (Industries and service organizations) continue to suffer awaiting an effective solution.

Regarding demand side, entrepreneurs, CEOs and General managers of industry and service organisations representing both state and private sector, top officers of industry associations, ministry officials, cross section including HR managers of firms covering both private, and public sectors, managers of companies that provide internships to students, and parents of university students (state and Private universities) were contacted. Since the spectrum of the responses are large only a representative sample was considered. However, a reasonable time was allocated for each respondent to cover the breadth of the research objectives.

\begin{tabular}{|c|c|}
\hline Category & Number \\
\hline Secretaries to leading ministries in Sri Lanka & 3 \\
\hline Vice chancellors & 3 \\
\hline Deans of various faculties in private and government universities, & 7 \\
\hline School principal & 1 \\
\hline Senior teachers (Government and private schools) & 2 \\
\hline Presidents of industry associations & 5 \\
\hline Officers of carrier development unit of higher education institutes & 2 \\
\hline Representatives from a university alumnus & 2 \\
\hline Current university students in Government sector & 2 \\
\hline Senior lecturers (Government and Private universities) & 6 \\
\hline Current students' Private universities & 2 \\
\hline CEO of companies & 1 \\
\hline General Managers of companies & 1 \\
\hline HR managers of leading firms covering both private, and public sectors & 2 \\
\hline Managers of Technical colleges & 1 \\
\hline Managers of companies that provide Internships to students & 3 \\
\hline Parents of university students (Government and Private universities) & 4 \\
\hline Total & 47 \\
\hline
\end{tabular}

Accordingly, a convenient sample of forty-seven opinion leaders representing all stakeholders of the education sector as per Table 1 was consulted. This sample size was chosen as a matter of judgment. Due to pandemic situation of Covid 19 
majority of meetings were converted to live interactive zoom meetings and telephone conversations. Due to practical reasons ministry secretaries were contacted through physical means due to difficulty connecting by virtual means. However, efforts have been made to maintain the quality of discussions despite these unavoidable circumstances during the period the study was conducted, and scheduled time frames were maintained. It was the researchers view; however, too large sample may hinder to carryout deep and comprehensive, case-oriented analysis that is the raison-d'etre of qualitative scientific investigation. The discussions were interactive, informal, non-time bound, and the data collection process was nonlinear, iterative thus researchers were able to capture more insights.

Narrative analysis method was used to administer reformulation of ideologies, experiences, cases, stories presented by respondents. However, representation from majority stratum was single or very small except few. Therefore, it was difficult find correlation or present different experiences of each respondent of each case were not possible. Therefore, the common methodology of developing coding, identifying themes, patterns and relationships were skipped. In other words, narrative analysis was limited to the revision of primary data by researchers and summarising them into relevant categories. A great deal of transformation of raw data to critical information through the brain processing of individual researcher was noted. Data collection was limited to be done by only one researcher to avoid subjectivity of the forming/interpreting information from the raw data and the time of data collection was extended significantly to ensure quality of the data collected for the research to achieve the objectives of research

Secondary data were collected through domestic and international publications. Primary and secondary data comparisons were done as appropriate. Since the respondents (except ministry secretaries) were having general opinions rather than precise statistics, comparing the findings of interview with the findings of literature review and identifying differences between them was done. Search for missing information, statistics that were not available with respondents to support the claims were synchronised at this stage. Comparing primary data with the phenomena focused on the study namely, psychological paradigm of students' degree choice was viewed under different perspective at this stage. The employability survey of Wayamba University of Sri Lanka was considered as one of the key sources as it reveals highly relevant data pertaining to this study. Statistics of other state universities in Sri Lanka also was considered. Annual reports and analysis of international institutions such as International Bank for Reconstruction and Development (IBRD); The World Bank; United National Industrial Development Organization (UNIDO); World Economic Forum (WEF); United Nations Educational, Scientific and Cultural Organization (UNESCO) were used extensively, and comparison were done with domestics reports as appropriate. Reports of Department of Census and Statistics, University Grants Commission, Central Bank of Sri Lanka, Ministry of Education, Department of Examinations have been referred to evaluate comments received in the interview process.

\section{FINDINGS}

Recent sociological rational choice theories argue that educational decisions are made with the objective of maximizing both economic and social returns to education Jæger (2007). Education is a powerful tool that enables underprivileged or minority groups to gain equal rights. Although formal education is a stressful activity in multiple age categories people are committed to study as it creates hope for the future. Access to education, is a basic human right according to global 
understand. This fact is recognized in the Universal Declaration of Human Rights and the United Nations Convention on the Rights of the Child is also a strategic development investment IBRD (2009). Giving people hope that they can improve their lot in life is one of the more powerful effects education has on a society. In addition, education reduces violence and crime in societies. Education leads to research and development. Systematic education is important because it helps members in a society learn from the mistakes of the past as they could compare results through the knowledge and experience, they gain. Israel (2018). Values such as respect, empathy, equality, and solidarity should be at the core of future higher education institutions and their missions UNESCO IESALC (2021). Countries have committed to prioritize progress for those who're furthest behind. The sustainable development goals (SDGs) are designed to end poverty, hunger, AIDS, and discrimination against women and girls. The creativity, knowhow, technology, and financial resources from all of society is necessary to achieve the SDGs in every context. The 17 SDGs are integrated-they recognize that action in one area will affect outcomes in others, and that development must balance social, economic, and environmental sustainability. On the other hand, education helps developing countries to reap these benefits by learning from those who are successful and through research and innovation by unleashing the potential of the human mind. And there is no better tool for doing so than education (IBRD-WB, 2011).

Education and training leads to knowledge, skills, and competence (KSC). Educationists use the Blooms Taxonomy in facilitating learning achievement from lower-level knowledge acquisition to higher order thinking Hyder and Bhamani (2016). This model was primarily conceptualised for the purpose to ensure learning transforms cognitive domain in higher education into higher levels of thinking, rather than a mere act or process of remembering the facts. It further reveals citing many references, student motivation at the higher education level is influenced by the assessment practices of the university. As higher education increases the KSC level, the productivity of the individual may increase. Also, higher skilled individuals qualify for different types of jobs than lower skilled individuals This is win-win for both supply and demand side explained above. In other words, students get higher wages and other fringe benefits, and the existence of educational institutes will be established. Similarly, industry sectors and service organization get competent workforce ensuring the product and services are more sustainable. These systematic improvements will create better future to the society. High skilled jobs usually constitute attractive pecuniary return to higher education. The individual specific nonpecuniary return to higher education is the intrinsic or the consumption value of education, which is defined in section (Alstadsæter, 2004). This is the main motivator to select most lucrative academic stream in education. However, there are student centric constraints in the choice. For example, even if the engineering stream is comparatively attracting higher wages and prestige students those who are poor in mathematics reluctant to follow mathematics stream that leaders to engineering in tertiary education. In 2015 government initiated secondary level admissions to Engineering Technology Subject Stream Bio System Technology Subject stream expanding the horizon in higher end disciplines.

It was also revealed another paradox during the interviews. Some parents advise their children to follow commerce/art stream even if they are good in mathematics. This is due to the competition in finding a placement in government universities. This is sad situation, reason being lack of resources in the government universities to enrol all students who get minimum qualification to enter to universities. Within each academic stream such as medicine, engineering also there are limitations. As a result, some students even follow the secondary education 
against their true desire. By providing a better understanding of values attached to different aspects of life, we may encourage using better means to promote life satisfaction or pursuing other objectives by means that are more compatible with life satisfaction (and hence more effective) Jæger (2007). During the time that the university education is only restricted to state sector the students had no alternative other than leaving to another country to peruse higher education.

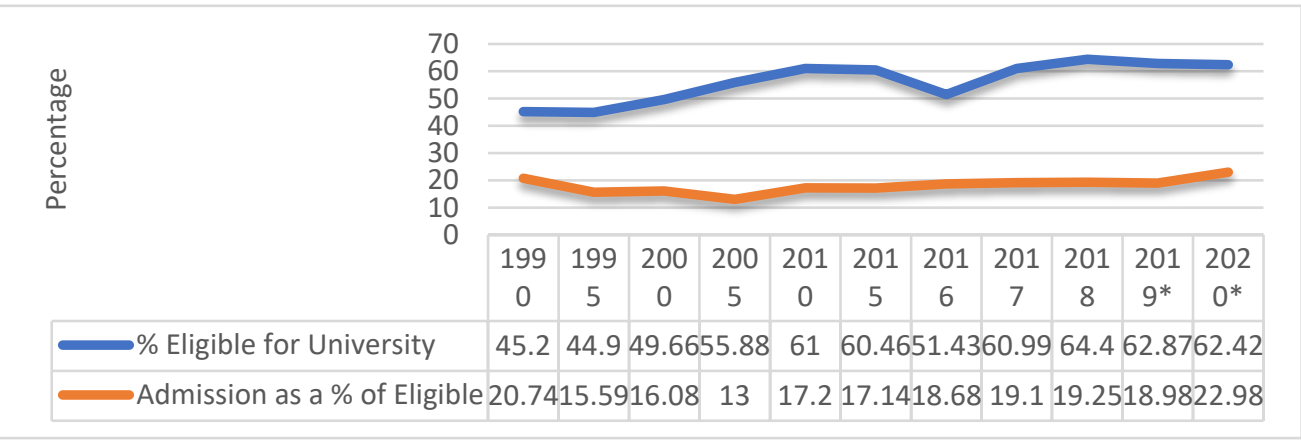

Figure 1 The flow and trend of students qualifying to tertiary level

Source: UGC (2021) * =Provisional

\section{The supply-side}

In Sri Lanka, students may enrol for the tertiary education under five main sources namely, State Universities; State Sector External degree programmes; Non state Sector Ministry of Higher Education Approved Degree awarding institutions; Non-State Sector trans-national Education providers; and SLIATE \& Private sector higher National Diploma providers. There is a competition among non-state higher education institutions to secure their share from those who failed to secure in state universities Edirisinghe et al. (2018)(Edirisinghe, Shen, \& Jin, The Direction of Maritime Education and Training development: A Conceptual Approach, 2018).

The government authorities seek the collaboration by the private higher education institutes to expand the current scope of academic streams Edirisinghe et al. (2017) (Edirisinghe, Shen, \& Wijeratne, Gender Imbalance and Trends in Tertiary Education: A case study in Capacity building in Maritime Industry, 2017). The formal accreditation is awarded in multiple ways for these degree awarding bodies. There are 15 government universities consisting 109 faculties and 675 departments. In addition to this there are 19 non university status institutes. This sector covers the free education system of the country. This expenditure as a percentage of total education expenditure counts to approximately $24 \%$. As per degrees of institutes recognized under section 25 A of the Universities Act No. 16 of 1978, there are 6 institutes under this category Degree awarding status granted by the Ministry of Education (Specified authority being the Secretary, Ministry of Education) there are 23 institutes under this category. Also 2 institutes under professional qualifications recognized as entry qualifications for postgraduate degrees. General Sir John Kotelawala Defence University was initially established as the "General Sir John Kotelawala Defence Academy" by the Parliamentary Act No 68 of 1981 and subsequently it was elevated to university status by the amendment Act No 27 of 1988. Sri Lanka association of non-state higher education institutes (SLANSHEI) is an umbrella organization formed with the initiation of seven leading institutes coming together to address the needs of the non-state higher education sector in the country in the year 2016. The seven founder members of the association are Sri Lanka Institute of Information Technology (SLIIT), CINEC Campus, Horizon Campus, Asian Pacific Institute of Information Technology (APIIT), Chartered Accountants of Sri Lanka (CA Sri Lanka), South Asian Institute of Technology and Management 
(SAITM) and Aquinas College of Higher Education. Apart from these founder members, SANASA Campus, Saegis, KIU and Gateway Graduate School currently act as its full member institutes.

1) University Grants Commission

Table 2 Universities and Higher Educational Institutions established under the purview of the University Grants Commission in Sri Lanka

\begin{tabular}{|c|c|}
\hline Category & Name of Institute \\
\hline \multirow[t]{15}{*}{ Universities } & University of Colombo \\
\hline & University of Peradeniya \\
\hline & University of Sri Jayewardenepura \\
\hline & University of Kelaniya \\
\hline & University of Moratuwa \\
\hline & University of Jaffna \\
\hline & University of Ruhuna \\
\hline & Open University of Sri Lanka \\
\hline & Eastern University, Sri Lanka \\
\hline & South Eastern University of Sri Lanka \\
\hline & Rajarata University of Sri Lanka \\
\hline & Sabaragamuwa University of Sri Lanka \\
\hline & Wayamba University of Sri Lanka \\
\hline & Uva Wellassa University \\
\hline & University for The Visual and Performing Arts \\
\hline \multirow[t]{19}{*}{ Institutes } & Postgraduate Institute of Medicine \\
\hline & Postgraduate Institute of Agriculture \\
\hline & Postgraduate Institute of Pali \& Buddhist Studies \\
\hline & Postgraduate Institute of Archaeology \\
\hline & Postgraduate Institute of Management \\
\hline & Postgraduate Institute of Science \\
\hline & Postgraduate Institute of English \\
\hline & Postgraduate Institute of Humanities \& Social Sciences \\
\hline & Postgraduate Institute of Indigenous Medicine \\
\hline & Institute of Human Resource Advancement \\
\hline & Institute of Indigenous Medicine \\
\hline & University of Colombo School of Computing \\
\hline & Gampaha Wickramarachchi Ayurveda Institute \\
\hline & National Institute of Library and Information Sciences \\
\hline & Institute of Technology University of Moratuwa \\
\hline & Institute of Biochemistry, Molecular Biology \& Biotechnology \\
\hline & National Centre for Advanced Studies in Humanities \& Social Sciences \\
\hline & Swamy Vipulananda Institute of Aesthetic Studies \\
\hline & Institute for Agro Technology and Rural Sciences \\
\hline \multirow[t]{2}{*}{ Campuses } & Sri Palee Campus \\
\hline & Trincomalee Campus \\
\hline
\end{tabular}

2) Other Government Universities/Institutes which are established by Acts of Parliament of Sri Lanka

Table 3 Government Universities/Institutes comes under category (ii) explained above

\section{Government}

affiliation
Educational Institute 


$\begin{array}{cr}\text { Ministry of Defense } & \begin{array}{r}\text { The General Sir John Kotelawala Defence University (KDU) General Sir } \\ \text { John Kotelawala Defence University (KDU) was initially established as the } \\ \text { "General Sir John Kotelawala Defence Academy" by the Parliamentary Act } \\ \text { No } 68 \text { of } 1981 \text { and subsequently it was elevated to university status by the } \\ \text { amendment Act No } 27 \text { of 1988, }\end{array} \\ \begin{array}{c}\text { Ministry of Higher } \\ \text { Education }\end{array} & \begin{array}{r}\text { Buddhist and Pali University of Sri Lanka } \\ \text { Ministry of } \\ \text { Vocational \& } \\ \text { Technical Training }\end{array} \\ \begin{array}{c}\text { Ministry of Skills } \\ \text { Development and }\end{array} & \text { Oniversity of Vocational Technology } \\ \text { Vocational Training } & \\ \text { Ministry of } & \text { National Institute of Education (NIE) } \\ \text { Education } & \end{array}$

3) Other Degree Awarding Institutes Recognized in Sri Lanka

Table 4 Degree Awarding Institutes comes under category (iii) explained above

Degrees of Institutes Recognized $\quad$ Institute of Surveying and Mapping
under Section 25 A of the

Universities Act No. 16 of 1978

Sri Lanka Institute of Information Technology (Guarantee) Limited.

Limited.
$\begin{gathered}\text { Ocean University of Sri Lanka. By virtue of the powers vested } \\ \text { in the sub section (I) of section } 71 \text { of the Ocean University of } \\ \text { Sri Lanka Act No.31 of } 2014 \text { the National Institute of Fisheries } \\ \text { and Nautical Engineering Act, No.36 of } 1999 \text { has been } \\ \text { replaced with effect from the } 17.06 .2015 \\ \text { National Institute of Social Development } \\ \text { National Institute of Business Management } * *\end{gathered}$

South Asian Institute of Technology and Medicine (Pvt) Ltd. (SAITM)

Degree awarding status granted National School of Business Management Limited (NSBM

by the Ministry of Education

(Specified authority being the

Secretary, Ministry of Education) Green University)

Colombo International Nautical and Engineering College (CINEC)

Sri Lanka International Buddhist Academy

The Institute of Chartered Accountants of Sri Lanka

SANASA Campus Limited

Horizon Collage of Business and Technology (Private) Limited

KAATSU Highly Advanced Medical Technology Training Centre (Pvt) Ltd

Nagananda International Institute for Buddhist Studies (pvt) Ltd

Sri Lanka Institute of Information Technology (Guarantee) Limited.

Aquinas College of Higher Studies

Institute of Technological Studies

South Asian Institute of Technology and Medicine (Pvt) Ltd. (SAITM)

\section{SLT Campus (Pvt) Ltd}

Saegis Campus (Pvt) Ltd 
Sri Lanka Institute of Nanotechnology (Pvt) Ltd

Esoft Metro Campus (Private) Limited

Institute of Chemistry Ceylon

International Collage of Business and Technology Limited.

Benedict XVI Catholic Institute of Higher Education (Private) Limited.

Royal Institute Colombo (Private) Limited

Business Management School (Private) Limited

International Institute of Health Science (Pvt) Ltd.

Professional Qualifications

Recognized as Entry

Qualifications for Postgraduate

Degrees
British Computer Society (BCS)

Sri Lanka Institute of Architects (SLIA)

(Source: https://www.ugc.ac.lk/)

The announcement of first degree by awarding institute under category (iii) was recorded in 1990 under Institute of Surveying and Mapping for Bachelor of Science (Surveying Science). This institute was established under Act No. 21 of 1969. Thereafter a significant shift in the paradigm of university education has taken place in 2013 with four institutes commencing degree programs namely, (a) The Institute of Chartered Accountants of Sri Lanka (Established under Act. No. 23 of 1959), (b) Sri Lanka International Buddhist Academy, (c) CINEC Campus Established in 1990 (Formally Colombo International Nautical and Engineering College), and (d) National School of Business Management Limited (NSBM Green University). These institutes were established under Companies Act. No. 07 of 2007.

\section{4) Recognition of Foreign Universities}

University Grants Commission recognizes foreign Universities/Higher Educational Institutes based on international acceptance. Universities/Higher Educational Institutes that are listed in the (i) Commonwealth Universities Yearbook (Published by Association of Commonwealth Universities) and (ii) International Handbook of Universities (Published by International Association of Universities) comes under this category. South Asian University (SAU) has announced admission to various Masters and Ph.D. programmes for its academic session 2020/21. UGC (2021). It is estimated that about 12,000 students enrol at the Open University and other State Universities to follow external and distance method of degrees. A further about 12,000 students leave for abroad to study undergraduate degrees in various countries every year EDB (2021). Around 26,000 students were considered to have entered private higher education institutions in 2014. It is clear from above statistics that students were simply deprived of their choice of education stream. They were compelled to accept what has been offered to them by the authorities until non state higher education institutes commenced operation. It is disturbing to note if someone can be made happy by providing something different to his or her choice. Education is probably more strongly correlated with future happiness throughout adulthood than any other variable (Stieg, 2020). Therefore, a need for a shift in the psychological paradigm in the students' choice has arisen in the present scenario.

\section{The Demand-side}


Department of Census and Statistics of Sri Lanka has categorized the employed population under main five sections namely, i) public sector; ii) private sector; iii) employers; iv) own account workers; and v) contributing family workers. Those who secure their education ultimately will join one of these employment categories to find their living.

\begin{tabular}{|c|c|c|c|c|c|c|c|c|}
\hline \multicolumn{9}{|c|}{ Table 5 Employed Population by status } \\
\hline $\begin{array}{c}\text { Industry } \\
\text { Group by } \\
\text { Status of } \\
\text { Employment }\end{array}$ & 2013 & 2014 & 2015 & 2016 & 2017 & 2018 & 2019 & 2020 (b) \\
\hline Public Sector & 1169504 & 1193062 & 1182914 & 1157658 & 1178708 & 1158474 & 1216549 & 1183716 \\
\hline Private Sector & 3109639 & 3152300 & 3213923 & 3437919 & 3555323 & 3474548 & 3521695 & 3411996 \\
\hline Employers & 231849 & 210687 & 242995 & 217215.1 & 247469.8 & 221194.1 & 209159.3 & 202787.7 \\
\hline $\begin{array}{l}\text { Own Account } \\
\text { Workers }\end{array}$ & 2474326 & 2461081 & 2531081 & 2511750 & 2571023 & 2586135 & 2658735 & 2657795 \\
\hline $\begin{array}{c}\text { Contributing } \\
\text { Family } \\
\text { Workers }\end{array}$ & 695962 & 683360 & 660064 & 623141.3 & 655654.8 & 574814.4 & 574554.5 & 542798.4 \\
\hline
\end{tabular}

(b) Provisional Source: Department of Census and Statistics

According to this there have been the highest percentage from the private sector (43\%) employees followed by own account workers 33\%). Public sector, employers, and contributing family workers are $15 \%, 3 \%$, and $7 \%$ respectively. Therefore, except for own account workers rest of $77 \%$ of the workforce need to cater to the demand available in the society. In other words. Unless the qualifications of supply side are rightly aligned with the demand of the industry it will lead to serious social problem. This problem is mainly two folded namely, unemployment and underemployment. While statistics are available for unemployment can be found it is rather difficult to get accurate details of underemployment.

\begin{tabular}{|ccccccc}
\hline Table 6 Trend of unemployed population & & & \\
\hline Period & $\begin{array}{c}\text { Household } \\
\text { Population } \\
\text { "000 } \\
\text { Persons }\end{array}$ & $\begin{array}{c}\text { Labour } \\
\text { Force } \\
\text { "000 } \\
\text { Persons }\end{array}$ & $\begin{array}{c}\text { Employed } \\
\text { "000 } \\
\text { Persons }\end{array}$ & $\begin{array}{c}\text { Unemployed } \\
\text { "000 } \\
\text { Persons }\end{array}$ & $\begin{array}{c}\text { Labour } \\
\text { Force } \\
\text { Participation } \\
\text { Rate \% }\end{array}$ & $\begin{array}{c}\text { Unemployment } \\
\text { Rate \% }\end{array}$ \\
\hline 2013 & $14,959.06$ & $8,033.80$ & $7,681.28$ & 352.53 & 53.71 & All \\
\hline 2014 & $15,134.48$ & $8,048.88$ & $7,700.49$ & 348.40 & 53.18 & 4.39 \\
\hline 2015 & $15,281.95$ & $8,214.47$ & $7,830.98$ & 383.50 & 53.75 & 4.33 \\
\hline 2016 & $15,448.68$ & $8,310.68$ & $7,947.68$ & 363.00 & 53.80 & 4.40 \\
\hline 2018 & $15,843.78$ & $8,566.63$ & $8,208.21$ & 359.00 & 54.07 & 4.19 \\
\hline 2019 & $16,196.23$ & $8,387.76$ & $8,015.17$ & 372.59 & 51.79 & 4.44 \\
\hline
\end{tabular}

Table 7 Employability Status of Applied Sciences Graduates

\begin{tabular}{|cccc|}
\hline Degree & $\begin{array}{c}\text { Total graduated } \\
\mathbf{2 0 1 7}\end{array}$ & $\begin{array}{c}\text { Unemployed } \\
\text { Unemployed } \\
\text { percentage }\end{array}$ & $\begin{array}{c}\text { (2) } \\
\text { B.Sc. (General) }\end{array}$ \\
B.Sc. (Joint Major) & 52 & 9 & 23 \\
\hline B.Sc. (Special) in Applied Electronics & 5 & 12 & 20 \\
\hline
\end{tabular}




\begin{tabular}{cccc}
\hline $\begin{array}{c}\text { B.Sc. (Special) in Mathematics with } \\
\text { Statistics }\end{array}$ & 5 & 0 & 0 \\
$\begin{array}{c}\text { B.Sc. (Special) in Industrial } \\
\text { Management } \\
\quad \text { Total }\end{array}$ & 6 & 0 & 0 \\
$\begin{array}{c}\text { Data Source: ESR - WUSL (2017) } \\
\text { M }\end{array}$ & 97 & 22 & 23
\end{tabular}

However, 38 percent of these graduates are ultimately end up employing in the field that are not relevant (50\% or less relevant) to the programs they followed in the university. In other words, there is a mismatch in the areas of teaching in the tertiary education and the real demand in the job market.

\begin{tabular}{|ccccccc}
\hline Table 8 Relevancy of the job to the study programme \\
Degree & Relevancy of the job to the study programme \\
\hline BSc (General) & $\mathbf{1 0 \%}$ & $\mathbf{2 5 \%}$ & $\mathbf{5 0 \%}$ & $\mathbf{7 5 \%}$ & $\mathbf{1 0 0 \%}$ \\
\hline BSc. (Joint Major) & 0 & 2 & 9 & 6 & 0 \\
\hline BSc (Special) in Applied Electronics & 1 & 1 & 1 & 0 & 1 \\
\hline BSc (Special) in Mathematics with Statistics & 2 & 0 & 0 & 0 & 2 \\
\hline BSc (Special) in Industrial Management & 0 & 0 & 1 & 2 & 3 \\
\hline Total respondents & 3 & 7 & 16 & 21 & 21 \\
\hline Percentage share & 4 & 10 & 24 & 31 & 31 \\
\hline
\end{tabular}

Data Source: ESR - WUSL (2017)

People who are classified as underemployed include workers who are highly skilled but working in low-paying or low-skill jobs and part-time workers who would prefer to be full-time. This is different from unemployment in that the person is working but not at their full capability.

\begin{tabular}{|c|c|c|c|c|c|c|c|c|}
\hline \multicolumn{9}{|c|}{ Table 9 Employed Population by sector } \\
\hline $\begin{array}{l}\text { Industry } \\
\text { Group by } \\
\text { Sector (c) }\end{array}$ & 2013 & 2014 & 2015 & 2016 & 2017 & 2018 & 2019 & 2020 (b) \\
\hline Agriculture & 2321215 & 2222859 & 2244547 & 2153874 & 2140185 & 2043698 & 2071940 & 2169679 \\
\hline Industry & 1996730 & 2027426 & 2018171 & 2097503 & 2331494 & 2239262 & 2258421 & 2152746 \\
\hline Service & 3363335 & 3450205 & 3568259 & 3696306 & 3736500 & 3732206 & 3850332 & 3676668 \\
\hline Total & 7681280 & 7700489 & 7830976 & 7947683 & 8208179 & 8015166 & 8180693 & 7999093 \\
\hline \multicolumn{9}{|c|}{ (b) Provisional } \\
\hline
\end{tabular}

\begin{tabular}{|lcccccc}
\hline \multicolumn{7}{l}{ Table $\mathbf{1 0}$ Graduate employment relevance level of 12 departments } \\
\hline & & $\mathbf{1 0 \%}$ & $\mathbf{2 5 \%}$ & $\mathbf{5 0 \%}$ & $\mathbf{7 5 \%}$ & $\mathbf{1 0 0 \%}$ \\
\hline 1 & Agribusiness Management & 1 & 1 & 3 & 2 & 5 \\
\hline 2 & Biotechnology & 1 & 0 & 2 & 5 & 4 \\
\hline 3 & Horticulture \& Landscape Gardening & 0 & 2 & 3 & 8 & 7 \\
\hline 4 & Plantation Management & 1 & 1 & 2 & 7 & 10 \\
\hline 5 & Accountancy & 5 & 7 & 13 & 37 & 51 \\
\hline 6 & Banking \& Finance & 0 & 3 & 5 & 10 & 9 \\
\hline 7 & Business Management & 4 & 9 & 23 & 42 & 12 \\
\hline 8 & Insurance \& Valuation & 0 & 0 & 1 & 2 & 5 \\
\hline
\end{tabular}




$\begin{array}{ccccccc}9 & \text { Aquaculture \& Fisheries } & 0 & 0 & 3 & 4 & 4 \\ 10 & \text { Applied Nutrition } & 1 & 0 & 1 & 1 & 10 \\ 11 & \text { Food Science \& Technology } & 0 & 0 & 2 & 8 & 14 \\ 12 & \text { Livestock \& Avian Sciences } & 0 & 0 & 4 & 8 & 4 \\ & \text { Total respondents } & 13 & 23 & 62 & 134 & 135 \\ & \text { Percentage share } & 4 & 6 & 17 & 37 & 37\end{array}$

Data Source: ESR - WUSL (2017)

Only in Faculty of Applied Sciences (FAS) among all graduates of FAS has reported higher employment, i.e., $77 \%$ at the time of the survey. The respective degree programs are illustrated in Table 10.

It was reported that there were 57,000 unemployed graduates in Sri Lanka as of 31 December 2016 and this number may have increased by now with the graduates of 2017 and 2018.They conduct picketing every other day disturbing the social routine of the country and the economic impact of this issues is not difficult to understand. Theses graduates have failed to contribute to the economy not because of their fault. Their education has been facilitated by the taxpayers in the country. There is no return on investment from the most intelligent and qualified young talent of the country. Therefore, guiding students in the right direction for their tertiary education is becoming more critical than ever before. Generic employability skills are important because the labour market is intensely competitive, and employers are looking for people who are flexible, take the initiative and can undertake a variety of tasks in different environments. If the country produces more and more unemployed gradates the ultimate impact to the economy and society will be unbearable. This will lead to critical psychological repercussions unless a systematic approach is introduced through scientific research. Gradual increase of unemployed graduates can be observed from 2014 and 2017 and was reported as 38\% in 2017.

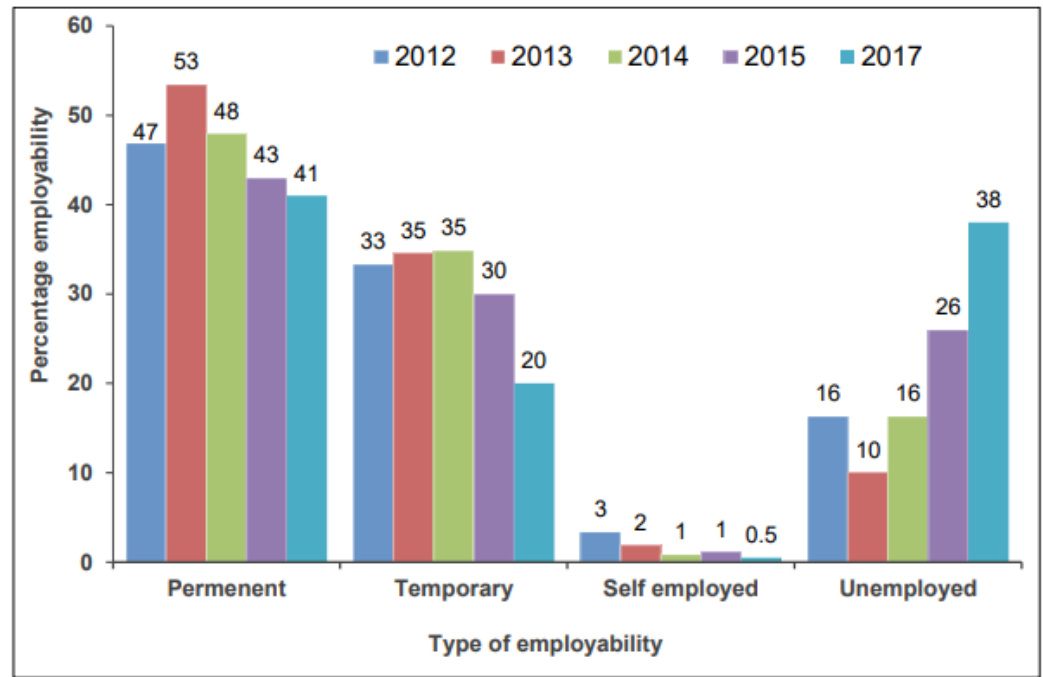

Figure 2 Mean employability of graduates of Wayamba University of Sri Lanka from year 2012 to 2017

Data Source: ESR - WUSL (2017)

Higher education should democratize digitalization, higher education actors should advocate for the right to connectivity, to a device, and to networking, e.g., through learning hubs UNESCO IESALC (2021). Employability is seen as one of the developmental parameters, and low employability leads to social deterioration and 
disruption that hampers the development of a country (Wickramasingh \& Wijenayake, 2017). The rate of un employability and the relevance of the area of tertiary education to the present employment of those employed is illustrated in Figure 2.

\section{Underemployment}

Underemployment is defined by Investopedia as a measure of employment and labor utilization in the economy that looks at how well the labor force is being used in terms of skills, experience, and availability to work Chen (2021). This is not explicit unless mass scale study is carried out for each job category to understand if the employees are contributing to the society commensurate with the education they have obtained. This is a crucial factor in countries like Sri Lanka because the tertiary education is only available to very limited percentage out of those qualified to enter to a university due to limited resources. In addition, they enjoy free education which is derived from the taxpayers. Therefore, unless the graduates are not utilised in their full capacity it is unfair by the society who facilitated their education. In Sri Lanka, even the primary and secondary education also provided free of charge. Therefore, any citizen who are underemployed or unemployed cannot justify the investment the government has made in giving their free education.

\section{DISCUSSIONS}

In general, choice refers to the ability of a consumer to decide which product or service from a range of possible options. This paper discussed fundamental prerequisites to create a psychological paradigm shift in students' degree choice. By owning the choice people become happy. According to rational choice theory people use rational evaluations to make rational choices. In these evaluations they ensure they can supersede their opportunity cost and achieve outcomes that are aligned with their own personal objectives. This theory believes that there is an invisible hand often associated with other concepts such as rational actors and self-interest. In economics' sense factors associated with rational choice theory are beneficial to the economy and widely discussed since Adam Smith's time. The availability of products and services to satisfy consumers needs and wants is one prerequisite. The consumers' ability to pay is another fundamental factor thus the financially capacity come into play.

The freedom to choose is considered a key factor in making a person happy. Is there a link between education level and personal happiness? Researchers defined happiness as a state of high mental well-being in which people "feel good and function well." Mcspadden (2015). It was discovered that the odds of happiness were equivalent throughout all levels of educational attainment which is somewhat paradoxical to the common understanding. Socioeconomic determinants including education not be applicable to programs aiming to increase mental well-being (MedicineNet, 2021). Do people enjoy education? One can go down own memory lane from primary education to present status and review if he or she genuinely enjoyed studies scarifying fun times, holidays, hobbies, and especially, memorizing difficult equations, facing stressful examinations, submitting academic assignments with tight schedules etc. Generally, education may be considered a non-utility function for majority in the society. There are few exceptions, and who may be born intellectuals that finds utils in studies and are self-motivated for education and academic related activities. Then what influence students for formal education. 
In the consumer decision making process, evaluation of alternatives comes as the third step before the purchase decision. However, unlike most of products and services, higher education consumer needs to fulfil certain other prerequisites. That is the consumers' ability to absorb the contents of the academic course modules. Just because someone likes to follow certain academic disciplines he or she cannot enrol to the programs. There are entry qualifications that need to be satisfied. For example, a student who is very weak in mathematics cannot be successful in selecting the engineering stream in the tertiary education. Usually, human intelligence, mental capacity that consists of the abilities to absorb course contents and learn from experience, adapt to changes, understand new concepts and theories, and finally use the knowledge to solve problems vary from person to person. For the Students in Class 12 having confusion in choosing their stream for masters. During this period, psychometric tests for students will help them to get a clear idea Lifology (2021). It is ideal for those students who have confusion in choosing their stream for Class 11 and 12. Aptitude tests help employers to analyse their candidates better. They focus on the candidate's stress responses, their personality traits and more importantly, their emotional quotient. Psychometric tests will be helpful for the children from Class 8 to Class 12 . This is the phase where children develop new perspectives and attitudes towards what they study. Therefore, a set of physical and mental queries intended to get a better understanding of the individual's conditioning. This test mainly focuses on a student's mental, psychological and emotional ability towards a particular area. After taking the psychometric test for students, candidates will get an understanding of their interests, aptitude, and personality, hence make the right career choice Lifology (2021).

The outcome of PPS helps to bridge the gap between the type of graduates produced in a country by universities (Supply side) and the characteristics of employees required in that country's government services and industry (Demand side). When the supply side experiences under employment and unemployment the society realises that there is a change need in the selection of education stream at least for the future generation. That is one of the key prerequisites that push the society towards a change. However, the human beings are reluctant to change and most of the time opting to change is the last cause of action by them. We are creatures of habit. Routines become automatic, but change jolts us into consciousness, sometimes in uncomfortable ways Kanter (2012). Therefore, unless there is a sufficient inducement to change, they delay this decision. Problem in higher education comes in this scenario because the outcome of the choice made today will be known after many years and it is impossible to reverse the situation then. On the other hand, demand side is derived from and influenced by the external environmental factors such as, political, economic, social, technology, environmental, ecological, and legal (or PESTEEL factors). These changes are another key prerequisite for a PSS. Thirdly, the country's higher education system should be capable of providing many options from which the candidates (supply side) to choose from. For example, until... Sri Lanka education system was limited to the options provided by the state namely, the University Grants Commission. Table... below illustrates that only $13-23 \%$ of students could enter to a state university thus they are compelled to accept what is offered to them by the government based on the merit and another filtering criteria namely, district basis. In other words, it the choice of the government and not the students. Therefore, the prerequisite for PSS does not exist under the state sector tertiary education. The budget proposal of 2017 accepted this to provide opportunities to students who became qualified at G. C. E. A/ L's but have missed out University Entrance due to aforesaid reasons. It was made possible through the student loan scheme where a 
maximum loan amount of Rs. 800,000 for the entire course of study could be provided on interest free basis EDB (2021). Annually, around 12,000 Sri Lankan students are estimated to go overseas for higher education opportunities. The drain on foreign exchange is estimated at $\$ 50$ million per annum Edirisinghe (2020)(Edirisinghe L., Leading the Children in Sri Lanka to Right Choice of Education, 2020). Percentage of enrolment in tertiary education in private institutions (\%) in Sri Lanka was reported at $12.06 \%$ in 2019 TE (2021).

\section{CONCLUSIONS}

Students, in terms of their mental and physical capacities, continue to develop until they are teens. As human traits constantly evolve with age and experience, it is advisable to test a psychometric test once a student has reached a stable level of development. There is another view that the first-time students might find the need for a psychometric test is at the time of transition from the 10th grade. They usually find the difficulty in choosing the right subject combination. This is where a psychometric test can be beneficial. However, students mainly get the opinion about their field of higher education from the parents, teachers, siblings, and peers. Therefore, iinitiating vertical integration mechanism between society, schools, universities, and the industry could be necessary. If the government provides free education to students at tertiary level it may be vital to lift any filtering mechanisms that is detrimental to their choices. If the entry criteria to higher education have not been evaluated according to future global trends a revision to selection criteria to university entrance is recommended. The authorities should introduce evolving new academic disciplines in the school curriculum and strengthen the vertical integration of those fields. These efforts should expand the horizon of academic disciplines to students at tertiary level. A suitable psychometric test should be made available to carry out effective SWOT analysis to students at different age levels and further technical and vocational education at tertiary level. In Sri Lanka a comprehensive report namely, Qualification Framework (SLQF) is now being used by the education authorities with the aim of creating an integral national framework for learning achievements by recognizing and accrediting qualifications offered by different institutions engaged in higher education and vocational training. It may be prudent to introduce benchmarks to bridge national vocational qualifications (NVQ) and SLQF. In NVQ the students need not any formal qualifications to get started. It facilitates a flexible route into chosen industry that leads to recognised qualification without any exams. It is also reminded to formally recognize and appreciate children with different skills and guide them to reach heights in what they are good at.

\section{ACKNOWLEDGEMENTS}

We acknowledge contribution by the Accelerating Higher Education Expansion and Development (AHEAD) Operation, a project funded by the World Bank. This paper constitutes of the main research conducted under the AHEAD project namely, Development of a mechanism that leads to a psychological paradigm shift in students' demand and choice for various academic disciplines in the tertiary education in Sri Lanka.

\section{REFERENCES}

APA. (2021, 10 1). APA Dictionary of Psychology. www.dictionary.apa.org : Retrieved from https://dictionary.apa.org/paradigm 
Chen, J. (2021, 06 30). Underemployment. Retrieved from www.investopedia.com : Retrieved

from https://www.investopedia.com/terms/u/underemployment.asp

Craft, M. (1984). Education for diversity. In Education and cultural pluralism. London and Philadelphia : Falmer Press.

EDB. (2021, 10 16). SLANSHEI CONTRIBUTION TO NON-STATE HIGHER EDUCATION SECTOR. Retrieved from Export Development Board: Retrieved from https://www.srilankabusiness.com/news/slanshei-contribution-tonon-state-higher-education-sector.html

Edirisinghe, L. (2018). Factors Affecting the Choice of Higher Education in Logistics and Transport in Sri Lanka. Colombo : National Centre for Advanced Studies.

Edirisinghe, L. (2020). Leading the Children in Sri Lanka to Right Choice of Education. CINEC Academic Journal, 4(1), 69-73. Retrieved from https://doi.org/10.4038/caj.v4i0.37

Edirisinghe, L., Ranwala, L., \& Siriwardena, S. (2021). Shaping the Education to Meet the Global Demands: Industrial Inclusiveness in University Curriculum. Sustainable Development Research, 28-38. Retrieved from https://doi.org/10.30560/sdr.v3n3p28

Edirisinghe, L., Shen, L., \& Jin, Z. (2018). The Direction of Maritime Education and Training development: A Conceptual Approach. Dalian: Dalian Maritime University.

Edirisinghe, L., Shen, L., \& Wijeratne, A. (2017). Gender Imbalance and Trends in Tertiary Education: A case study in Capacity building in Maritime Industry. Jaffna: University of Jaffna. Retrieved from https://papers.ssrn.com/sol3/papers.cfm?abstract_id=3014253

Fussell, R., \& Krauss, R. M. (ND). (2021) Social Psychological Models of Interpersonal Communication. New York: Columbia University and Mississippi State University.

Hyder, I., \& Bhamani, S. (2016). Bloom's Taxonomy (Cognitive Domain) in Higher Education Settings: Reflection Brief. Journal of Education and Educational Development. Retrieved from https://doi.org/10.22555/joeed.v3i2.1039

IBRD. (2009). The Towers of Learning Performance, Peril and Promise of Higher Education in Sri Lanka. Retrieved from www.worldbank.org: https://documents1.worldbank.org/curated/pt/713651468169160451/p df/507740WP0LK0To10Box342007B01PUBLIC1.pdf

Israel, M. (2018, 05 07). The Top Ten Effects Education has on Society. Retrieved 10 12, 2021, Retrieved from https://borgenproject.org/effects-education-hason-society/

Junejo, I., Amjad, H., Memon, R., Pujwani, Z., \& Rahar, U. (2019). Factors Affecting University Selection: Empirical Evidence from Hyderabad, Pakistan. Journal of Public Value and Administration Insights, 1-4. Retrieved from https://doi.org/10.31580/jpvai.v2i2.894

Jæger, M. (2007). Economic and Social Returns To Educational Choices: Extending the Utility Function. SAGE Journals. Retrieved from https://doi.org/10.1177/1043463107083739

Kanter, R. (2012, 09 25). Ten Reasons People Resist Change. Retrieved from Harvard Bubiness Review: Retrieved from https://hbr.org/2012/09/ten-reasonspeople-resist-chang

Koech, J., Bitok, J., Rutto, D., Koech, S., Okoth, J. O., Korir, B., \& Ngala, H. (2016). Factors Influencing Career Choices among Undergraduate Students in Public 
Universities in Kenya:A Case Study of University Of Eldoret. International Journal of Contemporary Applied Sciences, 50-63. Retrieved from http://ijcar.net/assets/pdf/Vol3-No2-February2016/03.pdf

Lifology. (2021, 10 3). Psychometric-test-for-students. Retrieved from www.lifology.com/: $\quad$ Retrieved from https://www.lifology.com/in/psychometric-test-for-students /

Mcspadden, K. (2015, 03 26). Education Does Not Make You a Happier Person. Retrieved from https://time.com : https://time.com/3759397/educationhappiness-mental-health/

Pedersen, P. (2001). Multiculturalism and the Paradigm Shift in Counselling: Controversies and Alternative Futures. Canadian Journal of Counselling. Retrieved from https://dev.journalhosting.ucalgary.ca/index.php/rcc/article/view/58661

Ramanayake , A., \& Pathiratne, L. (2012). Graduand Employment University of Sri Jayewardenepura, 2012. Sri Jayewardenepura: University of Sri Jayewardenepura.

Ranwala, L., Siriwardena, S., Kurukulaarchchi, V., \& Edirisinghe, L. (2020). Determinants of University Choice for the Academic Disciplines in The Tertiary Education in Sri Lanka. Colombo: Global Academic Research Institute. $\quad$ Retrieved from https://papers.ssrn.com/sol3/papers.cfm?abstract_id=3919326

TE. (2021). Sri Lanka - Percentage Of Enrolment In Tertiary Education In Private Institutions. Retrieved from https://tradingeconomics.com/ : https://tradingeconomics.com/sri-lanka/percentage-of-enrolment-intertiary-education-in-private-institutions-percent-wb-data.html

UGC. (2021, 10 02). Retrieved from University Grants Commission : https://www.ugc.ac.lk/index.php?option=com_content\&view=article\&id= 107\&Itemid $=40$

UNESCO IESALC. (2021, 5 26). Report on The Futures of Higher Education Envisions Collective and Holistic Responses to Global Challenges. Retrieved 10 5, 2021, from https://www.iesalc.unesco.org/en/2021/05/26/report-on-thefutures-of-higher-education-envisions-collective-and-holistic-responsesto-global-challenges /

UNESCO. (2021, 10 6). Right to education. Retrieved from en.unesco.org : https://en.unesco.org/themes/right-to-education

UNESCO. (2021a, 10 5). Higher education. Retrieved from /en.unesco.org : https://en.unesco.org/themes/higher-education

uis.unesco. (2021, 10 3). Higher Education. Retrieved from uis.unesco.org : http://uis.unesco.org/en/topic/higher-education 